\title{
Noguera, A. (2019). Revoltosas y revolucionarias. Mujeres y militancia en la Córdoba setentista. Córdoba, Argentina: Uni- versidad Nacional de Córdoba. 420 pp.
}

Cristina Viano ${ }^{1}$

Producto de largos años de un trabajo investigativo inspirado en preocupaciones enraizadas en su biografía familiar, Ana Noguera instala en el centro del análisis a las experiencias de las mujeres que alimentaron las dos grandes organizaciones político-militares de fines de los años sesenta y principios de los setenta: Montoneros y el Partido de Revolucionario de los TrabajadoresEjército Revolucionario del Pueblo (PRT-ERP). Pero lo hace focalizando su abordaje en esas revoltosas y revolucionarias que militaron en la Córdoba de los años setenta.

Una Córdoba que, como es sabido, ocupó un lugar central en distintos proyectos políticos y político-revolucionarios del periodo. Que fue un activo centro de militancia con capacidad de irradiación hacia otras regiones. $\mathrm{Y}$ allí una pregunta comienza a merodear en el texto: ¿Hay particularidades en el caso cordobés? Si la respuesta a esa pregunta fuera afirmativa ¿Cuáles son esas notas distintivas entonces? Consciente que colocar bajo análisis a un espacio regional específico reclama establecer un diálogo entre lo nacional y lo local (y también lo latinoamericano) la autora elude una respuesta taxativa a esas preguntas para recorrer un camino que la lleva a permanecer atenta a los matices, las complejidades, las similitudes pero también a las especificidades de una configuración sociohistórica de la que emerge un lugar propio para esas mujeres militantes. Un lugar activo para quienes fueron sometidas a una doble invisibilización, en tanto mujeres y en tanto integrantes de organizaciones clandestinas.

La perspectiva de género y la presencia de distintas incitaciones provenientes de la teoría feminista resultan vertebradoras en esta obra. Perspectivas que lejos de tomarse como un modelo rígido a aplicar resultan en un estímulo para interpelar, para tensionar, para escapar a tentaciones fáciles o estereotipos y marcar esos grises una experiencia sin dudas compleja. Se percibe asimismo el establecimiento de un diálogo amplio y generoso con las distintas producciones que habitan el campo de la Historia Reciente en general y la Historia Reciente con perspectiva de género en particular en Argentina.

La periodización que la recorre reconoce un margen de arbitrariedad dado que cada problema analizado reclama una genealogía y temporalidad que le son específicas. No obstante, en una ciudad donde modernidad y tradición se conjugaron de manera altamente contradictoria, el Cordobazo si bien mayo-

${ }^{1}$ Universidad Nacional de Rosario. Contacto: crisviano@gmail.com 
ritariamente masculino, conmovió los cimientos socio- culturales y constituyó para las mujeres una bisagra, una suerte de «bautismo de fuego» en la militancia revolucionaria sostiene Noguera.

A modo de sucinto inventario y recuperación selectiva de una obra rica en matices, precisemos que en sus páginas es posible visualizar la muy amplia participación de las mujeres al interior de las dos organizaciones y cómo ello fue cobrando vida a través de asambleas, conflictos gremiales y estudiantiles, en acciones armadas, en fugas de la cárcel, y también en la conformación de Frentes de mujeres.

Ahora bien, ¿Quiénes eran esas mujeres que se sumaron a la militancia revolucionaria?, ¿Qué las llevó a formar parte de esas organizaciones?, ¿Qué roles jugaron en su interior?, ¿cómo fueron las relaciones intergenéricas? ¿Cuánto de ruptura con los patrones de género de la época se atisba en sus prácticas militantes?, ¿Cómo se configuraron esas identidades femeninas al interior de un proceso agitado por profundas transformaciones políticas, sociales y también en las relaciones entre los géneros?

El libro, de cuidada edición y prolija estructura despliega sus argumentos inventariando y jerarquizando, al tiempo que presentando de manera clara y comprensible conclusiones parciales en cada uno de los ocho capítulos que lo componen y que inicialmente nos sumergen en los orígenes de las distintas organizaciones en el plano nacional y en el modo en que se gestaron en el plano local, sus ámbitos de inserción y sus lineamientos ideológico-políticos, para construir luego un retrato general de esas mujeres, desde una perspectiva cualitativa posibilitada por la vía testimonial. La Nómina de personas de Córdoba detenidas y asesinadas en los ' 70 s permite a su vez delinear los anclajes de clase, generacionales, socioeducativos y laborales de esa militancia local.

A la conformación de los frentes de masas y el lugar de las mujeres en las estructuras partidarias y particularmente en los frentes legales se aboca «Mujeres Montoneras», para luego detenerse en la Agrupación Evita de Córdoba que presentó un rasgo peculiar al acoplarse con la Coordinadora de Unidades Básicas Femeninas (CUBF). Los dos capítulos dedicados a las mujeres del PRTERP aparecen también animados por preocupaciones similares: develar el lugar de las mujeres en la organización y particularmente la creación y desarrollo de un Frente de Mujeres.

La participación de las mujeres en la lucha armada no se soslaya; aquí las dos organizaciones son analizadas de manera conjunta. Se aprecia un sugestivo cruce entre los muchos testimonios que la autora recogió, las imágenes de femineidad que se hallan presentes en la prensa gráfica del periodo y las conmemoraciones que realizan las publicaciones partidarias a las militantes asesinadas. La obra achica y agranda su campo de análisis. El empeño por trazar perfiles generales de la militancia o por el contrario el ensimismamiento en la reconstrucción de biografías de mujeres militantes con nombre y apellido le permiten revelar nuevas complejidades y recuperar así una dimensión humana generizada del pasado reciente. La reconstrucción biográfica que realiza de Raquel Liliana Gelín «la virgencita 
montonera» y de Nora Lía Marquardt, la Sargento Clara, «Ejemplo de Hombre Nuevo, de mujer revolucionaria», así lo indican.

Problematizando lo personal y lo político, cuya inestabilidad relacional se pone en juego en forma permanente, Noguera se adentra, por último, en la vida cotidiana de las militantes. El análisis de las transformaciones impulsadas en lo privado/cotidiano vinculadas a la construcción de una «nueva moral» sustento del Hombre Nuevo, de los códigos normativos, de la vida de pareja, de las maternidades o de las familias revolucionarias le permite observar tensiones y búsquedas alternativas a las configuraciones de género hegemónicas pero también reconocer que esas militantes fueron producto social de su época y que por tanto al interior de las organizaciones se siguieron sosteniendo y reproduciendo, aún con críticas de distintas intensidades, actitudes y prácticas que seguían modelos tradicionales.

El campo de la Historia Reciente en Argentina ha explorado profusamente distintos ángulos de esos (aún) con- troversiales años 60 y 70 imposibles de historizar sin considerar atentamente la experiencia cordobesa. Al interior de ese campo de estudios el cruce con la historia de las mujeres y los estudios de género ha constituido un espacio interseccional con trayectoria, aportes y en franca expansión, donde destacan los trabajos sobre la militancia de las mujeres que nutrieron en significativa proporción las organizaciones político militares del periodo. Sin embargo el estudio de Noguera constituye una valiosa obra sobre una temática cuyo recorte no había sido puesto en el foco de una investigación de manera sistemática como se hace en Revoltosas y revolucionarias. Obra que aporta al conocimiento de la militancia de las mujeres al interior de las dos principales organizaciones político armadas del periodo en un espacio de significación política como Córdoba, pero lo hace tomando distancia de algunos tópicos frecuentes que habitan el relato de la Historia Reciente (académica) para colocarse en una clave de comprensión situacionista de esas militancias femeninas. 